\title{
Reconstructing 130,000 years of East Asian air temperature variability using branched tetraether membrane lipids and clumped isotopes of land snail shells from the Chinese Loess Plateau
}

\author{
JINGJING GUO ${ }^{1}$, MARTIN ZIEGLER ${ }^{1}$, MIKE VREEKEN ${ }^{1}$, \\ SHIVAM MISHRA ${ }^{1}$, LOUISE FUCHS ${ }^{1}$, JIBAO DONG ${ }^{2}$, \\ YOUBIN SUN ${ }^{2}$ AND FRANCIEN PETERSE ${ }^{1}$ \\ ${ }^{1}$ Utrecht University \\ ${ }^{2}$ Institute of Earth Environment, Chinese Academy of Sciences \\ Presenting Author: j.guo@uu.nl
}

The Chinese Loess Plateau (CLP) is one of the best continuous paleoclimate archives on land, and its sediments host a unique archive of East Asian Monsoon (EAM) climate variability in the alternating layers of loess and paleosols reflecting glacial and interglacials, respectively. However, most of the currently available paleorecords represent a mixed signal of temperature and precipitation, which hampers a full understanding of this monsoon system, and the response of EAM precipitation on (future) atmospheric warming.

Here, we reconstruct a continuous, high-resolution air temperature record for monsoonal East Asia over the past 130,000 years based on temperature-sensitive soil bacterial membrane lipids, named branched glycerol dialkyl glycerol tetraethers (brGDGTs) stored in the Yuanbao section, located on the western edge of the CLP. The trends and absolute temperatures reflected by the brGDGT are independently confirmed by clumped isotope analysis (expressed as $\Delta_{47}$ ) of land snail shells stored in the same section. Our two independent palaeothermometers show an early warming over the last deglaciation, and interestingly, an absence of the Holocene Climate Optimum, whereas this is reflected by loess proxy records (magnetic susceptibility and grain size) from the same site. This suggests that temperature on the western CLP is more influenced by the cold and dry Westerlies instead of the East Asian summer monsoon during the last deglaciation. Despite clear millennial scale variations during marine isotope stage 3, temperature generally appears decoupled from the global-scale variations represented by the traditional loess proxies. This decoupling suggests that temperature at Yuanbao is influenced by local rather than global drivers, possibly resulting from its relatively high elevation (2200 $\mathrm{m}$ a.s.l.) and the vicinity of the Tibetan Plateau. 